\title{
FIRST RECORD OF Geoglossum fallax (Geoglossaceae, Ascomycota) IN THE SOUTHERNMOST REGION OF THE STATE OF BAHIA, NORTHEASTERN BRAZIL
}

\author{
PRIMEIRO REGISTRO DE Geoglossum fallax (Geoglossaceae, Ascomycota) NA \\ REGIÃO DO EXTREMO SUL DA BAHIA, NORDESTE DO BRASIL
}

\author{
Lorrane Rocha da SILVA ${ }^{1}$; Jorge Luiz FORTUNA ${ }^{1}$ \\ 1. Universidade do Estado da Bahia - UNEB, Campus X, Teixeira de Freitas, BA, Brasil. jfortuna@uneb.br
}

\begin{abstract}
Informally known as black earth tongue, Geoglossum fallax has a large terrestrial dark brown or black ascoma. The species belongs to the Geoglossomycetes class of fungi, which includes the genera Geoglossum, Sarcoleotia, Thuemenidium and Trichoglossum. This study describes the first record of G. fallax in Bahia, northeastern Brazil, and presents the species' main identification features. The specimens were found growing on a lawn, in Campus X, Bahia State University (UNEB), municipality of Teixeira de Freitas, southernmost region of Bahia state. After gross inspection and microscopy, all specimens were identified based on the specialized literature. Slides and exsiccata of specimens were deposited in the Fungi Collection, Fungal Biology Laboratory, Campus X, UNEB. This is the first record of G. fallax in northeastern Brazil.
\end{abstract}

KEYWORDS: Fungi Taxonomy. Earth Tongues. Geoglossomycetes.

\section{INTRODUCTION}

The fungus Geoglossum fallax (E. J. Durand, Annales Mycologici, VI(5):1-36, 1908) belongs to the Ascomycota phylum, Geoglossomycetes class, Geoglossales order, Geoglossaceae family, and Geoglossum genus.

Geoglossomycetes is a relatively small class, and the fungus species it incudes are commonly called black earth tongues. According to Hustad et al. (2013), Geoglossomycetes fungi are characterized by large, dark brown or black ascoma.

Kirk et al. (2008) and Schoch et al. (2009) classify the Geoglossales order in six genera and approximately 50 species. More specifically in Brazil, Pereira and Bezerra (2011) found that Geoglossum, Trichoglossum and Microglossum are the most common genera in the country. Ohenoja (1995) investigated Geoglossales and concluded that these saprobic fungi grow in lawns, pastures, prairies as well as along roads, rivers, and swamps.

Geoglossaceae includes terrestrial, stipitate, clavate or capitate, gymnocarpic black ascomycetes presenting inoperculate asci and generally septate, elliptical to cylindrical or clavate ascospores. When mature, in general these fungi are dark, resembling soot in aspect (ARAUZO; IGLESIAS, 2014).

The members of the Geoglossaceae family normally are terrestrial, with apothecial ascoma. Measuring up to $10 \mathrm{~cm}$ in height, these fungi have cartilaginous, serous consistency and may have a stipe. Color of ascomas may vary between black, black to violet, greenish, or yellowish (PEREIRA; BEZERRA, 2011).

Schoch et al. (2009) established that the Geoglossales order contains six genera (among which Geoglossum, Sarcoleotia and Trichoglossum), and that the Geoglossaceae family was previously placed in the Leotiomycetes class.

Currently, geoglossomycetes include the genera Geoglossum, Sarcoleotia, Thuemenidium and Trichoglossum, with 22, four, five, and 19 species each, respectively (KIRK et al., 2008).

This study describes the first record of $G$. fallax (Geoglossaceae, Ascomycota) in southern Bahia, northeastern Brazil, and discusses the main morphological characteristics that enabled its identification.

\section{MATERIAL AND METHODS}

All fungi identified as G. fallax were collected in the lawn of Campus X, Bahia State University (UNEB) $\left(17^{\circ} 33.316^{\prime} \mathrm{S}\right.$; 39 $\left.44.600^{\prime} \mathrm{W}\right)$, municipality of Teixeira de Freitas, state of Bahia, Brazil (collected in July 2017).

After photographic record of specimens in their original habitat, 10 individuals were collected and immediately taken to the Fungal Biology Laboratory, Campus X, UNEB. All material was submitted to gross inspection and microscopic analysis, and species was determined based on identification keys (DURAND, 1908; GEESTERANUS, 1965; OHENOJA, 1995; 
KUCERA; LIZON, 2012; ARAUZO; IGLESIAS, 2014; CANNON, 2016; RIDGE, 2016; SANCHEZIGLESIAS, 2017). Exsiccate of specimens and slides containing sections used in the microscopic analyses were deposited in the Fungi Collection, Fungal Biology Laboratory, Campus X, UNEB.

\section{RESULTS AND DISCUSSION}

The specialized literature describes G. fallax as a fungus species presenting dark, fleshy, firm, single $12 \mathrm{~mm}$ to $85 \mathrm{~mm}$ ascomata mildly spatuliform at the base; generally spatuliform $3 \mathrm{~mm}$ to $11 \mathrm{~mm}$ clavules containing the reproduction organ with one or two central, longitudinal grooves undifferentiated from stipes and between $3 \mathrm{~mm}$ and $11 \mathrm{~mm}$ in width; stipes varying between $1 \mathrm{~mm}$ and 3 $\mathrm{mm}$ in width; subcylindrical asci becoming clavate at the top, with eight ascospores and measuring 132 $\mu \mathrm{m}$ to $225 \mu \mathrm{m}$ in length and $16 \mu \mathrm{m}$ to $20 \mu \mathrm{m}$ in width, translucent to black or light brown long, thin, slightly curved ascospores with slightly curved, rounded ends with three to 14 septa (though the number of septa may vary between seven and 13) measuring $45 \mu \mathrm{m}$ to $115 \mu \mathrm{m}$ in length and $4 \mu \mathrm{m}$ to 7 $\mu \mathrm{m}$ in width; translucent or light brown, cylindrical, thin, septate, clustered, $2 \mu \mathrm{m}$ to $4 \mu \mathrm{m}$ thick paraphyses containing a generally elliptical to clavate or piriform apical cell that may be curved at the apex, measuring between $5 \mu \mathrm{m}$ and $12 \mu \mathrm{m}$ (ARAUZO; IGLESIAS, 2014; CANNON, 2016; HUSTAD et al., 2013; KUCERA; LIZON, 2012; OHENOJA, 1995; SCHOCH et al., 2009).

All G. fallax specimens collected and identified in this study presented the following characteristics: single, typically black $25 \mathrm{~mm}$ to 55 $\mathrm{mm}$ tall ascoma with a narrow base that enlarges slightly at the top; spatuliform clavula measuring 3 $\mathrm{mm}$ to $10 \mathrm{~mm}$ across presenting a longitudinal groove; stipes varying between $2 \mathrm{~cm}$ and $5 \mathrm{~cm}$ in height and $2 \mathrm{~mm}$ in width; claviform asci containing eight long ascospores measuring $150 \mu \mathrm{m}$ to $170 \mu \mathrm{m}$ in length and $17 \mu \mathrm{m}$ to $20 \mu \mathrm{m}$ in width; light brown, mildly curved ascospores measuring $100 \mu \mathrm{m}$ to 115 $\mu \mathrm{m}$ in length and $4 \mu \mathrm{m}$ to $5 \mu \mathrm{m}$ in width with eight to 13 septa (Figure 1).

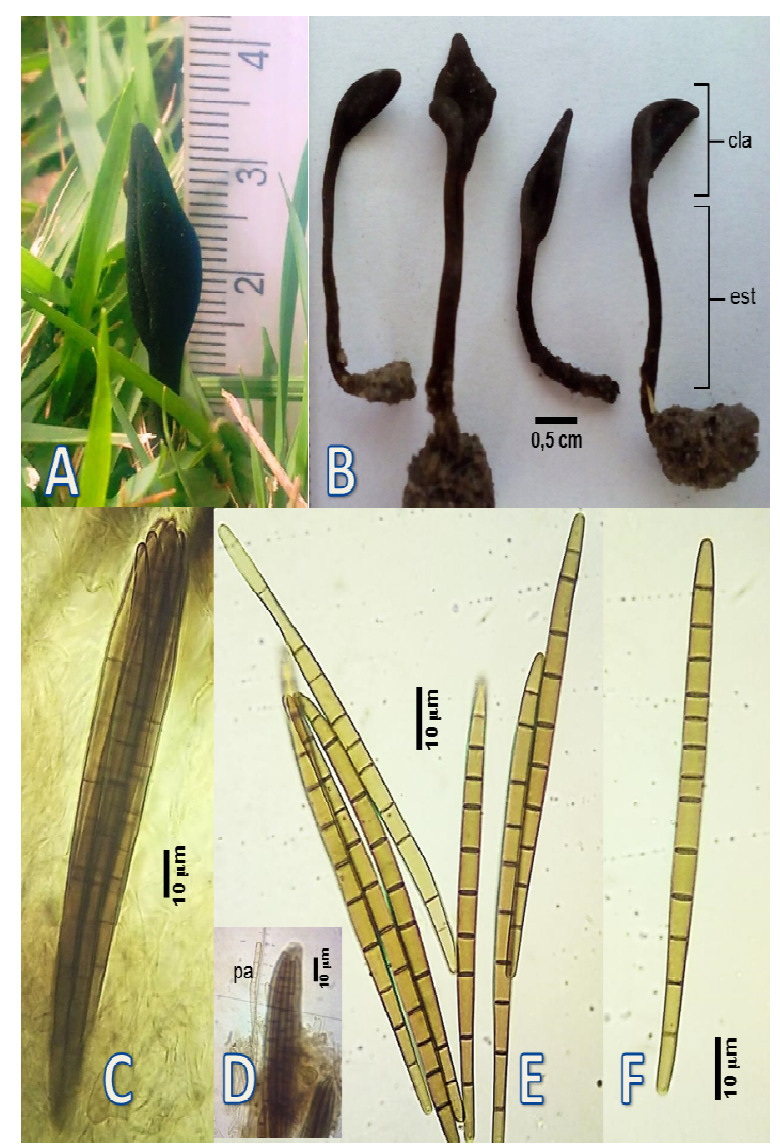

Figure 1. (A) Geoglossum fallax in its habitat. (B) Ascocarps: clavula (cla) and stipe (est). (C) Ascus. (D) Paraphysis (pa). (E) Ascospores with 9 to 11 septa. (F) Ascospore with 13 septa. (Microphotographs: 1,000X). 
Until 2008, no records of Geoglossaceae fungi were made in northeastern Brazil; however, a survey carried out by Pereira and Bezerra (2011) revealed the occurrence of Trichoglossum hirsutum in Charles Darwin Ecological Unit and in João de Vasconcelos Sobrinho Ecopark, state of Pernambuco, for the first time.

Kucera and Lizon (2012) claim that it is virtually impossible to assess the abundance of geoglossaceous fungi, because fruiting bodies emerge sporadically. This means that every new specimen found should to be examined accurately, since it may shed new light on the taxonomy and ecology of these species.

The climate in the southernmost region of the state of Bahia, Brazil, is tropical humid or subhumid with a short dry season whose consequences are offset by higher rainfall in the other seasons. August is the driest month, when rainfall stands at $58 \mathrm{~mm}$, while November is the rainiest, with 136 $\mathrm{mm}$. The hottest and coldest months are January and June, when temperatures reach $26.2^{\circ} \mathrm{C}$ and $22.0^{\circ} \mathrm{C}$, respectively. Also, mean temperature in Teixeira de Freitas is $23.4^{\circ} \mathrm{C}$, and mean rainfall is $1,099 \mathrm{~mm}$ (CLIMATE DATA, 2017). The most intense rains fall in November to January, and temperature maximums are recorded in December (KOUSKY; CHU, 1978; RAO; HADA, 1990; TANAJURA; GENZ; ARAÚJO, 2010).

Importantly, the present study shows that $G$. fallax managed to grow in a region that would otherwise pose adverse conditions to fungi of the Geoglossaceae family. Ascocarps emerged during atypical climate settings in the region (July 2017), when higher rainfall and lower mean temperatures were recorded compared to the time series for July. For Arauzo and Iglesias (2014), temperate conditions may favor the growth of $G$. fallax, since it prefers low temperatures and high humidity, which are not the climatic conditions normally observed in the southernmost region of the state of Bahia.

All in all, the data obtained allow concluding that this is the first record of G. fallax in the southernmost region of the state of Bahia and in northeastern Brazil. Thus, this finding becomes important for studies of taxonomy and ecology of fungi Ascomycota, because studies of Atlantic Forest fungal in the southernmost of Bahia are rare.

RESUMO: Conhecido como "língua-da-terra", o fungo Geoglossum fallax pertence à classe Geoglossomycetes e é tipicamente caracterizado por ascocarpo terrestre grande, escuro, variando de cor entre marrom-escuro a preto. Atualmente encontram-se incluídos na classe Geoglossomycetes os gêneros Geoglossum, Sarcoleotia, Thuemenidium e Trichoglossum. Os objetivos deste trabalho foram apresentar o primeiro registro da espécie G. fallax no extremo sul da Bahia, nordeste brasileiro, e descrever as principais características que permitiram sua identificação. Os espécimes foram encontrados em um gramado no Campus $\mathrm{X}$ da Universidade do Estado da Bahia (UNEB), município de Teixeira de Freitas. Todo o material foi analisado macro e microscopicamente e identificado com base na literatura especializada. Lâminas e exsicatas dos espécimes foram depositadas na Micoteca do Laboratório de Biologia dos Fungos, Campus X da UNEB. A identificação de G. fallax confirma o primeiro registro desta espécie no extremo sul da Bahia e no nordeste do Brasil.

PALAVRAS-CHAVE: Taxonomia de fungos. Língua-da-terra. Geoglossomycetes.

\section{REFERENCES}

ARAUZO, S.; IGLESIAS, P. 2014. La familia Geoglossaceae ss. str. en la península Ibérica y la Macaronesia. Revista Micológica Errotari, n. 11, p. 166-259.

CANNON, P. 2016. Geoglossum fallax. Fungi of Great Britain and Ireland. [online]. Disponível em: <fungi.myspecies.info/taxonomy/term/5109/descriptions> Acessado em 27 de dezembro de 2017.

CLIMATE-DATA. 2017. Climograma de Teixeira de Freitas. Clima: Teixeira de Freitas. [online]. Disponível em: <https://pt.climate-data.org/location/31961/> Acessado em 29 de dezembro de 2017.

DURAND, E. J. 1908. The Geoglossaceae of North America. Annales Mycologici, v. VI, n. 5, p. 1-36. 
GEESTERANUS, R. A. M. 1965. Geoglossaceae of India and adjacent countries. Persoonia. v. 4, p. 19-46.

HUSTAD , V. P.; MILLER, A. N.; DENTINGER, B. T. M.; CANNON, P. F. 2013. Generic circumscriptions in Geoglossomycetes. Persoonia, v. 31, p. 101-111. https://doi.org/10.3767/003158513X671235

KIRK, P. M.; CANNON, P. F.; MINTER, D. W.; STALPERS, J. A. 2008. Ainsworth and Bisby's Dictionary of the Fungi. 10. ed. Wallingford: CAB International University Press, Cambridge.

https://doi.org/10.1079/9780851998268.0000

KOUSKY, V. E.; CHU, P. S. 1978. Flutuations in annual rainfall for northeast Brazil. Journal Meteorological Society Japan, v. 56, p. 457-465. https://doi.org/10.2151/jmsj1965.56.5_457

KUCERA, V.; LIZON, P. 2012. Geoglossaceous fungi in Slovakia III. The genus Geoglossum. Biologia, v. 67, n. 4, p. 654-658. https://doi.org/10.2478/s11756-012-0053-6

OHENOJA, E. 1995. Occurrence of Geoglossum, Trichoglossum and Microglossum (Ascomycota, Leotiales) in Finland. Documents Mycologiques, Tome XXV, n. 98-100, p. 285-294.

PEREIRA, L. T.; BEZERRA, J. L. 2011. Trichoglossum hirsutum (Geoglossaceae, Ascomycota): primeiro registro para o Nordeste brasileiro. Scientibus Série Ciências Biológicas, v. 11, n. 1, p. 90-101. https://doi.org/10.13102/scb145

RAO, V. B.; HADA, K. 1990. Characteristics of rainfall over Brazil: annual variations and connections with the southern oscillation. Theoretical and Applied Climatology, v. 42, p. 81-91.

https://doi.org/10.1007/BF00868215

RIDGE, I. 2016. Beninners Guide to Earth Tongues. NWFG Newsletter. [online]. Disponível em: <http://fungus.org.uk/nwfg/earth-tongues.htm> Acessado em 22 de dezembro de 2017.

SCHOCH, C. L.; WANG, Z.; TOWNSEND, J. P.; SPATAFORA, J. W. 2009. Geoglossomycetes cl. nov., Geoglossales ord. nov. and taxa above class rank. in the Ascomycota Tree of Life. Persoonia, v. 22, p. 129136. https://doi.org/10.3767/003158509X461486

TANAJURA, C. A. S.; GENZ, F.; ARAÚJO, H. A. 2010. Mudanças climáticas e recursos hídricos na BAHIA: validação da simulação do clima presente do HADRM3P e comparação com os cenários A2 e B2 para 20702100. Revista Brasileira de Meteorologia, v. 25, n. 3, p. 345-358. https://doi.org/10.1590/S010277862010000300006 